\title{
Helminth parasites of the digestive tract of the harbour porpoise Phocoena phocoena in Danish waters: a comparative geographical analysis
}

\author{
M. Victoria Herreras ${ }^{1, *}$, Sølvi E. Kaarstad ${ }^{1}$, J. Antonio Balbuena ${ }^{1}$, Carl Chr. Kinze ${ }^{2}$, \\ J. Antonio Raga ${ }^{1}$
}

${ }^{1}$ Department of Animal Biology, University of Valencia, Dr. Moliner 50, E-46100 Burjasot, Valencia, Spain

${ }^{2}$ Zoological Museum, Universitetsparken 15, DK-2100 Copenhagen $\varnothing$, Denmark

\begin{abstract}
Most studies of the helminth fauna of the harbour porpoise Phocoena phocoena have focused on taxonomy, associated pathologies and surveys reporting prevalence and abundance of the parasite species. This study (1) characterizes the helminth fauna of the digestive tract of the harbour porpoise in Danish waters and (2) examines the influence of some factors structuring helminth communities within the host's geographical range. Seventy digestive tracts loesophagus, stomachs, duodenal ampulla and intestines) were analysed. We found 5 helminth species (Anisakis simplex, Hysterothylacium aduncum, Pholeter gastrophilus, Bolbosoma sp. and Diphyllobothrium sp.). Gastric ulcers associated with $A$. simplex were observed in 8 of the 28 porpoises infected with this parasite and gastric cysts produced by $P$. gastrophilus were observed in 2 of 70 porpoises analysed. No other pathologies were observed. The presence of $H$. aduncum and $P$. gastrophilus was the main difference between this study and a previous survey in the same area. Our data were compared with those of other analyses of helminth faunas from different harbour porpoise distribution areas. The geographical analysis suggested the presence of a strong local influence determining the helminth fauna, the cestode Diphyllobothrium stemmacephalum being the only species which could be considered as a specialist of the harbour porpoise. The intestinal helminth community of this host represents the most depauperate community recorded so far in a cetacean.
\end{abstract}

KEY WORDS: Nematoda Cestoda. Trematoda Acanthocephala Phocoena phocoena. Cetacea

\section{INTRODUCTION}

The harbour porpoise Phocoena phocoena (L., 1758) is a small cetacean with coastal habits which is limited to the cold temperate and subarctic waters of the Northern Hemisphere. The species is distributed in 3 isolated areas: the North Pacific, the North Atlantic and the Black Sea (Klinowska 1991). Recently, there has been considerable interest in the harbour porpoise because of fears that the population is declining (International Whaling Commission 1984), mainly as a result of serious levels of incidental fishery mortality in European and North American waters (Donovan \& Bjørge 1995).

The majority of helminthological studies of the harbour porpoise have focused on North Atlantic popula-

•E-mail: maria.v.herreras@uv.es tions and dealt with the taxonomy (Wesenberg-Lund 1947, Arnold \& Gaskin 1975, Gibson \& Harris 1979), associated pathologies (Smith 1989, Baker \& Martin 1992) and surveys reporting the prevalence and abundance of the parasite species (Clausen \& Andersen 1988, Lick 1991). This study reports the helminth fauna of the digestive tract (oesophagus, stomach, and intestine) of harbour porpoises in Danish waters. In addition, we have reviewed previous helminthological information throughout the host's range to elucidate the influence of local and historical factors in the helminth community of the digestive tract.

\section{MATERIALS AND METHODS}

Seventy harbour porpoises $(42$ males and 28 females with a wide range of ages: 0 to $12 \mathrm{yr}$ for females and 
0 to 13 yr for males) were collected from strandings or as by-catches between 1988 and 1990. Sixty-seven porpoises were obtained in the Skagerrak, Kattegat and adjacent waters, while only 3 were taken in the North Sea.

Stomachs and intestines were obtained from frozen carcasses and examined for parasites. All stomach compartments were analysed. The intestines were opened longitudinally and surveyed along their whole length. Helminths from the stomach and intestine were collected separately. A total recovery of parasites was attempted. The parasites were extracted from the mucosa or separated from food items using a $600 \mu \mathrm{m}$ mesh sieve.

Nematodes, acanthocephalans and cestodes were fixed and preserved in $70 \%$ ethanol. Stomach cysts were preserved in formalin $10 \%$. All specimens of each species were identified and counted to obtain the prevalence and abundance (terminology of Margolis et al. 1982). Voucher specimens will be deposited in the Parasitic Worm Section of the Natural History Museum in London (ref. no. 1996.10.1.1-4, 1996.10.1.5-14).

A comparative analysis of the harbour porpoise's helminth fauna was made based on all previous surveys available to us. In total, 8 data sets were examined (including this study). Despite the low number of studies available, the data cover the entire distribution of the harbour porpoise (North Atlantic, North Pacific and Black Sea). The comparison was based on prevalences and presence or absence of species, because other information was not available in all cases (see Table 2).

\section{RESULTS}

A total of 8110 helminth specimens belonging to 5 species were found: Anisakis simplex, Hysterothylacium aduncum (Nematoda), Diphyllobothrium sp. (Cestoda), Pholeter gastrophilus (Trematoda) and Bolbosoma sp. (Acanthocephala).
Helminth fauna was clearly dominated by anisakid nematodes both in individual hosts and in the total sample of porpoises (Table 1). Anisakis simplex was the most abundant and prevalent species, accounting for $82.6 \%$ of all the helminths recovered (Table 1). Gastric ulcers associated with this species were observed in 8 of the 28 porpoises infected with this species. Gastric cysts produced by Pholeter gastrophilus appeared in 2 of 70 porpoises analysed. No other parasite-induced pathologies were observed. The other anisakid species, Hysterothylacium aduncum, represented $17.32 \%$ of all the helminths recovered.

The quantitative contribution of the remaining species was low (Table 1). Only 1 adult female of Bolbosoma sp. and 2 Diphyllobothrium sp. specimens were found in the stomach and intestines, respectively. The condition of this material precluded identification at specific level. However, based on morphological resemblances and previous biogeographical evidence, Diphyllobothrium sp. may likely correspond to $D$. stemmacephalum.

The geographical analysis reveals that Anisakis simplex is the most widely distributed species, appearing in 7 of the 8 surveys. In addition, this species seems common in most of the localities, its prevalence being over $40 \%$ in 4 localities (Table 2 ).

Other species seem to be common locally but they are absent in certain areas. For example, other anisakid nematodes (Pseudoterranova decipiens, Krabbe, 1878; Contracaecum osculatum, Rudolphi, 1802; Phocascaris sp., Myers, 1957; and Hysterothylacium aduncum) had a prevalence $>30 \%$ only in some areas of the North Atlantic. Likewise, the stomach trematode Pholeter gastrophilus (Kossack, 1910) has been recorded only in 3 localities (British coast, Danish waters and the Black Sea). Diphyllobothrium stemmacephalum, the most frequently recorded intestinal helminth, shows a high prevalence $(40 \%)$ only in the Black Sea. The digeneans of the genus Hadwenius have been reported only in porpoises from the Pacific.

Table 1. Helminth parasites of the digestive tract of the harbour porpoise Phocoena phocoena from Danish waters. Dominance is expressed as the percentage of worm individuals of a particular species with respect to the total number of worms of all species

\begin{tabular}{|c|c|c|c|c|c|c|}
\hline \multirow[t]{2}{*}{ Helminth species } & \multirow[t]{2}{*}{ Site } & \multirow{2}{*}{$\begin{array}{c}\text { Prevalence } \\
(\%)\end{array}$} & \multirow{2}{*}{$\begin{array}{c}\text { Abundance } \\
(\bar{x} \pm \mathrm{SD})\end{array}$} & \multirow{2}{*}{$\begin{array}{l}\text { Abundance } \\
\text { range }\end{array}$} & \multicolumn{2}{|c|}{ Dominance $[\%]$} \\
\hline & & & & & Per host $(\bar{x} \pm \mathrm{SD})$ & Whole sample \\
\hline \multicolumn{7}{|l|}{ Nematoda } \\
\hline Anisakis simplex & Stomach, intestine & 51.42 & $95.49 \pm 369.03$ & $0-2812$ & $48.19 \pm 48.09$ & 82.6 \\
\hline Hysterothylacium aduncum & Stomach, intestine & 45.71 & $20.36 \pm 69.90$ & $0-439$ & $49.36 \pm 47.82$ & 17.32 \\
\hline Acanthocephala & & & & & & \\
\hline Bolbosoma sp. & Stomach & 1.42 & $0.01 \pm 0.12$ & $0-1$ & $0.01 \pm 0.08$ & 0.01 \\
\hline Cestoda & & & & & & \\
\hline Diphyllobothrium sp. & Intestine & 2.85 & $0.03 \pm 0.17$ & $0-1$ & $2.43 \pm 14.58$ & 0.02 \\
\hline Trematoda & & & & & & \\
\hline Pholeter gastrophilus & Stomach & 2.85 & - & - & - & - \\
\hline
\end{tabular}


Table 2. Geographical comparison of the helminth fauna of the digestive tract of the harbour porpoise. Data given are given as prevalences $(\%)$

\begin{tabular}{|c|c|c|c|c|c|c|c|c|c|}
\hline \multirow{2}{*}{ Helminth species } & \multicolumn{9}{|c|}{ Locality (literature sources given below) } \\
\hline & $\begin{array}{c}\text { NE } \\
\text { Pacific" }\end{array}$ & $\begin{array}{l}\text { SE New- } \\
\text { foundland }\end{array}$ & $\begin{array}{c}\text { Azov } \\
\text { Black Sed }^{c}\end{array}$ & $\begin{array}{l}\text { E North } \\
\text { Sea }^{\mathrm{d}}\end{array}$ & $\begin{array}{l}\text { W Baltic } \\
\text { Sed }^{d}\end{array}$ & $\begin{array}{l}\text { SE Scot- } \\
\text { land" }\end{array}$ & $\begin{array}{l}\text { British } \\
\text { waters' }\end{array}$ & $\begin{array}{l}\text { Danish } \\
\text { waters }^{q}\end{array}$ & $\begin{array}{l}\text { Danish } \\
\text { waters }^{\text {h }}\end{array}$ \\
\hline N & 4 & 80 & 76 & 53 & 47 & 7 & 41 & 149 & 70 \\
\hline Anisakis simplex & 50.0 & 47.5 & - & 132 & 34 & 42.9 & 43.0 & 16.8 & 38.6 \\
\hline Contracaecum osculatum & - & 83.8 & - & - & - & - & - & - & - \\
\hline Pseudoterranova decipiens & - & - & - & 13.2 & - & - & - & - & - \\
\hline Phocascaris sp. & - & 30.0 & - & - & - & - & - & - & - \\
\hline Pholeter gastrophilus & - & - & 31 & - & - & - & 34.0 & - & 2.8 \\
\hline Hadwenius mironovi & 25.0 & - & - & - & - & - & - & - & - \\
\hline Hadwenius nipponicus & 50.0 & - & - & - & - & - & - & - & - \\
\hline Bolbosoma sp. & 25.0 & $6.9^{\circ}$ & - & - & - & - & - & - & 1.4 \\
\hline Tetrabothrius sp. & - & 1.3 & - & - & - & - & - & - & - \\
\hline Diphyllobothrium sp. & - & - & - & - & - & - & - & - & - \\
\hline Diphyllobothrium stemmacephalum & - & $6.9^{\bullet}$ & 40 & - & - & - & - & 0.6 & 2.9 \\
\hline \multicolumn{10}{|c|}{ 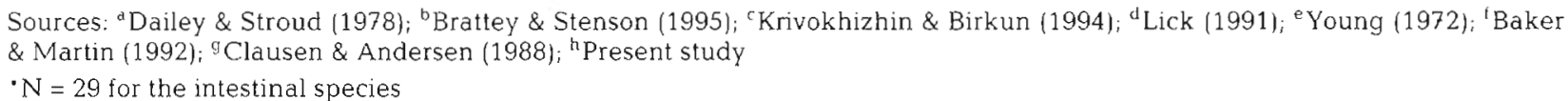 } \\
\hline
\end{tabular}

Bolbosoma sp. and the cestode Tetrabothrius sp. have only been recorded occassionally and with a low prevalence (Table 2).

\section{DISCUSSION}

The results of this study are consistent with previous surveys in the same area (Clausen \& Andersen 1988), the exceptions being Hysterothylacium aduncum and Pholeter gastrophilus, which are reported here. The definitive hosts of this nematode are various fish species, mainly gadids (Berland 1961), which in turn constitute an important part of the porpoises' diet in Danish waters (Aarefjord 1993). Thus, we consider that $H$. aduncum is an accidental parasite whose presence in the porpoises results from the ingestion of infected fish. For this reason, we have not regarded this species as a part of the helminth community of the harbour porpoises and it was consequently not included in the global comparison.

The helminth communities in individual hosts depend on the parasites in the host population (host specialists) and those in the host community (host generalists) (Holmes 1987). In the gut of the harbour porpoise, the geographical comparison suggests that the communities are dominated by generalists in all the areas analysed. Anisakis simplex was the most common species in almost all localities, being recorded in more than 30 cetacean and 12 pinniped species (Kagei 1969, Young \& Lowe 1969, Davey 1971, Margolis \& Arai 1989). However, electrophoretic studies (Nascetti et al. 1986) have shown various sibling species of $A$. simplex and therefore records may refer to different species. Further biogeographical studies are neccesary to evaluate the degree of specialisation of each A. simplex sibling species. In any case, the absence of Anisakis spp. in the Black Sea might be due to the particular physical and chemical characteristics of this area (Tomczak \& Godfrey 1994). Likewise, the trematode Pholeter gastrophilus is a well-known generalist of odontocetes (see Raga 1994 and references therein).

The influence of sympatric hosts in determining the helminth communities of the harbour porpoises is evident in some localities of the North Atlantic (southwestern Newfoundland and eastern North Sea; Table 2). In these areas, different anisakids of seals (Contracaecum osculatum, Phocascaris sp. and Pseudoterranova decipiens) were reported from porpoises. Brattey \& Stenson (1995) related a high number of C. osculatum in the porpoises of southwestern Newfoundland with the abundance of several phocid species (Halichoerus grypus, Phoca groenlandica, Cystophora cristata) in the area. These authors suggested that the harbour porpoise is an accidental host of $C$. osculatum and Phocascaris sp., since all the specimens found were larvae.

The acanthocephalans of the genus Bolbosoma and tetrabothriid cestodes have been recorded mainly in pelagic cetaceans (Hoberg 1987, Hoberg et al. 1993). In these studies, the presence of Bolbosoma sp, in North Pacific and North Atlantic localities and of Tetrabothrius sp. off Newfoundland may result from occasional exchanges with pelagic hosts. These data are consistent with the suggested importance of the local host assemblage in shaping the helminth communities of the harbour porpoise. The 2 species of the genus Hadwenius ( $H$. mironovi and $H$. nipponicus) have been 
recorded so far only in North Pacific porpoises (Ching \& Robinson 1959, Dailey \& Stroud 1978). The biogeographical data available on these 2 species are at present scarce, making it difficult to establish their degree of host specialisation. However, H. mironovi has been reported in belugas (Delphinapterus leucas) in the North Atlantic (Adams \& Rausch 1989) and the North Pacific (Krotov \& Delyamure 1952, Delyamure 1964) and H. nipponicus in Dall's porpoises (Phocoenoides dalli) in the North Pacific (Yamaguti 1951). This evidence at least suggests that these 2 species are not strict host specialists, although we cannot rule out the possibility that they are local specialists in Pacific porpoises. However, if this were the case, the absence of the parasites in the other localities would strongly indicate that this has not been a long host-parasite association.

Our analyses show that Diphyllobothrium stemmacephalum is the most common intestinal species of this host (Table 2). This species has been occasionally reported in other cetaceans, such as the long-finned pilot whale Globicephala melas and the bottlenose dolphin Tursiops truncatus (Balbuena \& Raga 1993a), but published records suggest that the harbour porpoise is the most comon host (see historical accounts in Delyamure (1955), Delyamure et al. (1985) and Andersen (1987)]. Therefore, $D$. stemmacephalum might be the only host specialist of the digestive tract of the harbour porpoise, at least in the North Atlantic and Black Sea populations (Table 2). Although further evidence is needed, it seems that this species has not colonised the porpoises in the North Pacific. In fact, D. stemmacephalum is possibly absent in these waters, previous records in Japanese waters being questionable (see Balbuena \& Raga 1993a).

The evidence brought forward here reveals a strong local influence in the shaping of the helminth communities of the digestive tract of the harbour porpoise, depending mostly on the presence of sympatric hosts, particularly marine mammals. This contrasts with the lung-worm communities of the harbour porpoise, which seem primarily determined by a long hostparasite co-evolutionary association (Balbuena et al. 1994). The harbour porpoise has one of the most species-poor helminth communities, specifically in the intestine, compared with other cetaceans (Wazura et al. 1986, Balbuena \& Raga 1993b, Aznar et al. 1994). However, additional data from other cetaceans are required to establish the reason for such species differences.

Acknowledgements. We are grateful to Dr Mercedes Fernández for assistance with parasite collection and to Dr David Gibson and Ms Eileen Harris from the Natural History Museum (UK) for their help with species determination. This study was supported by the Danish Goverment (Projekt Marsvin) and DGICYT from the Spanish Government (Project No. PB92-875).

\section{LITERATURE CITED}

Aarefjord H (1993) Enaeringsøkologi hos nise (Phocoena phocoena) i skandinaviske farvann. Masters Thesis, Biologisk Institutt, Universitetet i Oslo

Adams AM, Rausch RL (1989) A revision of the genus Orthosplanchnus Odhner, 1905 with consideration of the genera Odhneriella Skrjabin, 1915 and Hadwenius Price, 1932 (Digenea: Campulidae). Can J Zool 67:1268-1278

Andersen KI (1987) A redescription of Diphyllobothrium stemmacephalum Cobbold, 1858 with comments on other marine species of Diphyllobothrium Cobbold, 1858. J Nat Hist 21:411-427

Arnold PW, Gaskin DE (1975) Lungworms (Metastrongyloidea:Pseudaliidae) of harbour porpoise Phocoena phocoena (L., 1758). Can J Zool 53:713-735

Aznar FJ, Balbuena JA, Raga JA (1994) Helminth communities of Pontoporia blainvillei (Cetacea: Pontoporiidae) in Argentinian waters. Can J Zool 72:702-706

Baker JR, Martin AR (1992) Causes of mortality and parasites and incidental lesions in harbour porpoises (Phocoena phocoena) from British waters. Vet Rec 130:554-558

Balbuena JA, Aspholm PE, Andersen KI, Bjørge A (1994) Lung-worms (Nematoda:Pseudaliidae) of harbour porpoises (Phocoena phocoena) in Norwegian waters: patterns of colonization. Parasitology 108:343-349

Balbuena JA, Raga JA (1993a) Diphyllobothriids (Cestoda: Pseudophyllidea) from the long-finned pilot whale Globicephala melas (Traill, 1809) off the Faroe Islands, with comments on the taxonomy of Diphyllobothrium Cobbold, 1858 species from cetaceans. Syst Parasitol 26:117-126

Balbuena JA, Raga JA (1993b) Intestinal helminth communities of the long-finned pilot whale (Globicephala melas) off the Faroe Islands. Parasitology 106:327-333

Berland B (1961) Nematodes from some Norwegian marine fishes. Sarsia 2:1-50

Brattey J, Stenson GB (1995) Helminth parasites of the alimentary tract of the harbour porpoise, Phocoena phocoena (L.), from Newfoundland and Labrador. J Helminthol Soc Wash 62(2):209-216

Ching HL, Robinson ES (1959) Two campulid trematodes from a new host: the harbour porpoise. J Parasitol 45:181

Clausen B, Andersen S (1988) Evaluation of bycatch and health status of the harbour porpoise. Dan Rev Game Biol 13(5): $1-20$

Dailey $M$, Stroud, R (1978) Parasites and associated pathology observed in cetaceans stranded along the Oregon coast. $\mathrm{J}$ Wild! Dis 14:503-511

Davey JT (1971) A revision of the genus Anisakis Dujardin, 1845 (Nematoda: Ascaridata). J Helminthol 45:51-72

Delyamure SL (1955) Helminth fauna of marine mammals (ecology and phylogeny). Akad Nauk SSSR, Moscow, p 522 (Israel Program for Scientific Translations, Jerusalem 1968)

Delyamure SL (1964) Beluga (Delphinapterus leucas) investigations of the species. In: Kleinenberg SE, Yablokov AV, Be'lkovich BM, Tarasevich MN (eds) Enemies and parasites. Izv Akad Nauk SSSR, Moscow, p 292-312 (Israel Program for Scientific Translations, Jerusalem 1969)

Delyamure SL, Skrjiabin AS, Serdyukov AM (1985) Diphyllobothrisds - tapeworms of man, mammals and birds. In: Sudarikov EV (ed) Pnnciples of cestodology, Vol 11 Nauka USSR, Moscow, p 200 (in Russian)

Donovan GP, Bjørge A (1995) Harbour porpoises in the North Atlantic: edit extract from the Report of the IWC Scientific Committee, Dublin. In: Bjørge A, Donovan GP (eds) Biology of the phocoenids. Rep Int Whal Comm (Spec Iss) $16: 3-25$ 
Gibson DI, Harris EA (1979) The helminth parasites of cetaceans in the collections of the British Museum (Natural History). Invest Cetacea 10:309-324

Hoberg EP (1987) Recognition of larvae of Tetrabothriidae (Eucestoda): implications for the origin of tapeworms in marine homeotherms. Can J Zool 65:997-1000

Hoberg EP, Daoust PY, MacBurney S (1993) Bolbosoma capitatum and Bolbosoma sp. (Acantocephala) from sperm whales (Physeter macrocephalus) stranded on Prince Edward Islands, Can. J Helminthol Soc Wash 60:205-210

Holmes JC (1987) The structure of helminth communities. In: Howell MJ (ed) Parasitology, Quo vadit? Proc 6th Int Congr Parasitol, Aust Acad Sci, Camberra, p $27-45$

International Whaling Commission (1984) Report of the subcommittee on small cetaceans. Rep Int Whal Comm 34: $144-145$

Kagei N (1969) Life history of nematodes of the genus Anisakis. Fish Res Bd Can (Transl Ser) 1324:25

Klinowska M (1991) Dolphins, porpoises and whales of the world. The IUCN Red Data Book. IUCN, Gland

Krivokhizhin S, Birkun A Jr (1994) Some changes in the helminth fauna of Black Sea dolphins. In: Evans PGH (ed) European research on cetaceans 8. Proc 8th Ann Conf Eur Cetacean Soc. Lugano, p 238-239 (abstract)

Krotov AI, Delyamure SL (1952) Some aspects of the parasitic worm fauna of mammals and birds of URSS. Tr Gel'mintol Lab 6:278-292 (in Russian)

Lick RR (1991) Untersuchungen zu Lebenszyklus (Krebse, Fische, marine Säuger) und Gefrierresistenz anisakider Nematoden in Nord- und Ostsee. PhD dissertation, Institut für Meereskunde, Universität Kiel

Margolis L, Arai HP (1989) Parasites of marine mammals. In: Kennedy MJ (ed) Synopsis of the parasites of vertebrates of Canada. Alberta Agriculture, Animal Health

Responsible Subject Editor: M. D. Dailey, Gunnison, Colorado, USA
Division, Alberta, p 1-26

Margolis L, Esch GW, Holmes JC, Kuris AM, Schad GA (1982) The use of ecological terms in parasitology (report of an ad hoc committee of the American Society of Parasitologists). J Parasitol 68:131-133

Nascettı G, Paggi L, Orecchia P. Smith J, Mattiucci S, Bullini $L(1986)$ Electrophoretic studies on the Anisakis simplex (Ascarida: Anisakidae) from the Mediterranean and North-East Atlantic. Int J Parasitol 16:633-640

Raga JA (1994) Parasitismus bei dem Cetacea. In: Duguy R, Robineau D (eds) Handbuch der Säugetiere Europas, Meeressäuger Teil I: Wale und Delphine. Aula-Verlag, Wiesbaden, p 132-145

Smith JW (1989) Ulcers associated with larval Anisakis simplex B (Nematoda: Ascaridoidea) in the forestomach of harbour porpoises Phocoena phocoena (L.). Can J Zool 67 : $2270-2276$

Tomczak M, Godfrey JS (1994) Regional oceanography: an introduction. Pergamon, Oxford, p 297-309

Wazura KW, Strong JT, Glenn CL, Bush AO (1986) Helminths of the beluga whale (Delphinapterus leucas) from the Mackenzie River Delta, Northwest Territories. J Wildl Dis $22: 440-442$

Wesenberg-Lund $E$ (1947) On three parasitic nematodes from Cetacea. Vidensk Medd Dan Naturhist Foren 110:17-30

Yamaguti $S$ (1951) Studies on the helminth fauna of Japan. Part 45. Trematodes of marine mammals. Arb Med Fak Okayama 7:283-294

Young PC (1972) The relationship between the presence of larval anisakine nematodes in cod and marine mammals in British home waters. J Appl Ecol 9:459-483

Young PC, Lowe D (1969) Larval nematodes from fish of the subfamily Anisakinae and gastrointestinal lesions in mammals. J Comp Pathol 79:301-313

Manuscript first received: June 24, 1996

Revised version accepted: November 1, 1996 